\title{
PENGARUH PEMBERIAN MIXED JUICE TERHADAP ASUPAN ENERGI IBU BERSALIN
}

\author{
Sri Maharani \\ Prodi DIII Kebidanan, Sekolah Tinggi Ilmu Kesehatan Baiturrahim Jambi \\ Email:maharanibarus@gmail.com
}

\begin{abstract}
The process of labor, especially the second stage of increased contraction in the uterine muscle that causes decreased blood supply and oxygen needed by muscles to convert glucose into energy. Anaerobic metabolism usually occurs in activities that require large energy and briefly.This study to analyze differences in energy intake in mothers giving birth between those who were given mixed juice and those who were given the freedom to consume food and beverages during labor. This study uses randomized controlled trial design, single blinded. There was a significant difference in control group energy intake and intervention group ( $p<0.05)$. Giving mixed juice during delivery in maternal mothers affects maternal satisfaction and the difference of maternal energy intake, but there is no difference in lactate levels of infants born.
\end{abstract}

Keywords: Energy intake, Mixed Juice

\begin{abstract}
ABSTRAK
Proses persalinan terutama kala II terjadi peningkatan kontraksi pada otot rahim yang menyebabkan menurunnya suplai darah dan oksigen yang dibutuhkan oleh otot untuk mengubah glukosa menjadi energi. Metabolisme anaerobik biasanya terjadi pada kegiatan yang memerlukan energi besar dan secara singkat. Penelitian ini bertujuan untuk menganalisis perbedaan asupan energi pada ibu bersalin antara yang diberikan mixed juice dan yang diberi kebebasan konsumsi makanan dan minuman selama persalinan. Penelitian ini menggunakan desain randomized controlled trial, single blinded. Terdapat perbedaan yang bermakna pada asupan energi kelompok kontrol dan kelompok intervensi $(\mathrm{p}<0,05)$. Pemberian mixed juiceselama persalinan pada ibu bersalin berpengaruh terhadap perbedaan asupan energi ibu bersalin.
\end{abstract}

Kata kunci : Asupan Energi, Mixed Juice

\section{PENDAHULUAN}

Proses persalinan terutama kala II terjadi peningkatan kontraksi pada otot rahim yang menyebabkan menurunnya suplai darah dan oksigen yang dibutuhkan oleh otot untuk mengubah glukosa menjadi energi. Metabolisme anaerobik biasanya terjadi pada kegiatan yang memerlukan energi besar dan secara singkat. Energi yang dihasilkan berasal dari proses glikolisis dan simpanan fosfokrantin yang memecah glukosa dari cadangan glikogen yang ada diotot dan hati. Metabolisme anaerobik selain menghasilkan energi, juga menghasilkan produk sampingan berupa asam laktat. Kala II 
dibutuhkan energi dalam jumlah besar secara singkat, sehingga apabila laktat yang semakin meningkat dan tidak diubah menjadi glukosa maka akan terjadi peningkatan kadar laktat yang dapat mengakibatkan penumpukan asam laktat yang merupakan indikator kelelahan pada ibu bersalin. Agar tidak menggunakan cadangan glikogen yang terlalu berlebihan di dalam tubuh, maka selama persalinan memerlukan asupan nutrisi dari makanan/ minuman dari luar tubuh sebagai sumber glukosa. ${ }^{1}$

Kebutuhan nutrisi ibu bersalin sama dengan kebutuhan pada umumnya, ibu bersalin memerlukan kebutuhan baik karbohidrat, protein, lemak, vitamin dan mineral yang sama, hanya saja pada ibu bersalin terjadi perubahan baik dari segi fisiologi dan psikologis, sehingga terjadi peningkatan kebutuhan nutrisi selama persalinan. Perubahan fiologis yang terjadi pada ibu bersalin dikarenakan pada masa persalinan terjadi penghambatan pengosongan lambung karena adanya perubahan hormonal pada ibu bersalin dimana bentuk cairan berkisar 10 sampai 60 menit, sedangkan bentuk padat berlangsung 3 sampai 4 jam, sehingga pada ibu bersalin membutuhkan asupan nutrisi yang mudah diserap dan diubah menjadi energi sehingga, dibutuhkan sumber energi dalam bentuk fruktosa. ${ }^{4}$

Madu dipakai merupakan sumber karbohidrat yang tinggi yaitu sebanyak $95 \%$ dari berat kering madu.Kurma merupakan tanaman multiguna yang memiliki serat, karbohidrat, mineral dan vitamin. Buah kurma memiliki indeks glikemik yang rendah, sehingga digunakan sebagai sumber energi yang direkomendasikan. Jambu dipilih karena memiliki rasa yang enak dan memiliki warna yang terang sehingga apabila rasa yang dominan enak dan memiliki warna yang menarik untuk kepuasan subyek penelitian.Buah mangga dipilih karena memiliki karbohidrat pada daging buahnya terdiri dari gula sederhana, tepung, dan selulosa. Gula sederhananya berupa sukrosa, glukosa dan fruktosa yang memberikan rasa manis dan bermanfaat bagi pemulihan tenaga pada tubuh manusia. Buah jeruk memiliki sebagian besar air yang berguna sebagai cairan untuk pembuatan jus, selain itu jeruk mengandung karbohidrat sederhana (gula) fruktosa, glukosa dan sukrosa, serta asam sitrat yang juga dapat memberikan sejumlah kecil energi. Kacang merah merupakan sumber protein nabati yang penting, selain itu juga memiliki asam amino seperti sistin dan metionin dan sebagai sumber lemak tak jenuh yang berfungsi untuk memenuhi kebutuhan protein dan lemak pada mixed juice. Bahan yang mengandung karbohidrat berguna sebagai sumber energi. ${ }^{5-11}$

Berdasarkan kebutuhan nutrisi ibu bersalin, peneliti membuat makanan/ minuman untuk ibu bersalin dengan gabungan bahan madu, buah dan kacang yang mempunyai khasiat baik terhadap kebutuhan karbohidrat, elemen elektrolit, sumber protein dan lemak yang semuanya akan memperbaiki metabolisme otot rahim dan metabolisme suplai makanan ke janin. Mixed juicedibuat untuk ibu bersalindimana dalam pembuatannya memperhitungkan kebutuhan asupan 
nutrisi ibu bersalin, yang diharapkan dapat memenuhi kebutuhan selama persalinan dan terutama pada kala II, sehingga pembuatan jus dicampurkan dari beberapa jenis buah dan bahan yang dapat mencukupi kebutuhan energi ibu bersalin dan mudah diserap sehingga diubah menjadi energi. Berdasarkan penjelasan diatas peneliti tertarik melakukan penelitian mengenai "Pengaruh Pemberian Mixed juice terhadap Asupan Energi Ibu Bersalin."

\section{METODE PENELITIAN}

Metode dalam penelitian ini yaitu Randomized Controlled Trial (RCT) post test only control group design. Penelitian ini dilakukan di lima Puskesmas PONED yang ada diKota Bandung, yaitu Puskesmas Garuda, Puter, Padasuka, Ibrahim Aji dan Pagarsih yang dilakukan pada bulan Maret-April 2017. Jumlah sampel pada penelitian ini sebanyak 60 responden terdiri dari dua kelompok yaitu, 30 responden kelompok perlakuan yang akan diberikan mixed juiceselama persalinan, dan 30 responden kelompok kontrol yang akan diberikan kebebasan mengkonsumsi makanan dan minuman selama persalinan. Tetapi dalam pelaksanaannya terdapat drop out pada kelompok perlakukan sebanyak 10 responden dan kelompok kontrol sebanyak 7 responden. Kriteria inklusi pada penelitian ini adalah Ibu hamil yang akan melahirkan yang berusia 20-35 tahun, ibu hamil yang akan melahirkan <4 dengan fase laten, ibu yang melahirkan bayi aterm, tunggal dan sehat, ibu dengan Indeks Masa tubuh ( IMT) normal sebelum hamil 18,5-24,9 kg/m², ibu yang bersedia menjadi subjek penelitian. Kriteria eksklusi adalah Ibu yang mempunyai alergi makanan tertentu, merokok, konsumsi alkohol dan obat-obatan terlarang, ibu yang mengalami komplikasi pada masa kehamilan seperti diabetes melitus, hyperemesis gravidarum dan hipertensi, ibu dengan riwayat penyakit gastritis, ibu dengan riwayat gangguan metabolisme seperti hipoglikemi, hiperglikemia, dislipidemia, hipokolesterolemia, hiperkolesterolemia. Kriteria drop out adalah ibu tidak mengkonsumsi minuman persalinan sesuai dengan aturan yang telah diberikan yaitu minimal 100 kkal selama kala I dan kala II, ibu mengundurkan diri, saat intervensi ataupun kontrol diberikan, ibu dengan penyulit seperti induksi persalinan serta persalinan dengan alat dan section caesaria, gawat janin, kelainan his (hipertonus), persalinan memanjang pada primigravida kala I > 12 jam, kala II $>2$ jam dan kala III >30 menit sedangkan pada multigravida kala I $>$ 8 jam, kala II > 1 jam dan kala III > 30 menit.

Penelitian ini diawali dari Pengajuan izin studi pendahuluan ke Klinik Padjadjaran Jatinangor untuk melakukan studi pendahuluan, setelah dilakukan studi pendahuluan 30 subjek penelitian tentang pengalaman ibu mengenai nutrisi dan hidrasi selama persalinan, kemudian menganalisis masalah yang ibu alami mengenai konsumsi nutrisi selama persalinan yang ibu alami dan menganalisis kebutuhan ibu bersalin dalam hal konsumsi nutrisi selama persalinan.Menelaah kebutuhan yang dibutuhkan ibu bersalin dalam hal pemenuhan nutrisi ibu bersalin yang 
sesuai kebutuhan ibu bersalin. Menetapkan pembuatan minuman persalinan dalam bentuk mixed juice agar mudah diserap menjadi energi yang dibutuhkan ibu bersalin sesuai kebutuhan energi ibu selama persalinan. Menentukan bahan-bahan yang mengandung energi yang dibutuhkan ibu bersalin yaitu 100 $\mathrm{kkal} / \mathrm{jam}$, dengan membuat beberapa formulamixed juice dan melakukan uji organoleptik kepada panelis semi pakar untuk memilih satu formula, setelah didapatkan formula terpilih kemudian dibuat 2 varian rasa mixed juice. Dengan bahan-bahan mixed juicevarian rasa pertama buah jambu biji merah, kurma, madu, jeruk, sari kacang merah kering rebus, dan varian rasa kedua mangga, kurma, madu, jeruk, sari kacang merah kering rebus. Setelah itu mengurus perizinan penelitian dan melakukan persiapan penelitian.

Setelah didapatkan mixed juiceyang sesuai dengan kebutuhan ibu bersalin selanjutnya merekrut 5 orang bidan sebagai enumerator untuk memperoleh kesamaan prosedur dan persepsi terhadap penelitian yang dilakukan. Pengumpulan data dimulai dengan memilih ibu yang akan melahirkan yang memenuhi kriteria inklusi. Ibu yang datang bersalin ke Puskesmas PONED Kota Bandung diberikan konseling tentang pemenuhan nutrisi dan hidrasi selama persalinan yang mana pada kehamilan trimester akhir sudah dijelaskan dan diminta kesediaannya menjadi subjek penelitian, dengan berkoordinasi dengan bidan setempat serta diminta kesediaannya kembali untuk ikut serta dalam penelitian dengan menandatangani formulir informed consent. Bagi yang menolak memberikan persetujuan penelitian maka tidak diikutkan ke dalam penelitian.

Pemilihan subjek penelitian dilakukan oleh peneliti.Selama proses penelitian dilakukan oleh enumerator dipantau 2 jam satu kali selama fase. Enumerator bertugas untuk memantau jumlah minuman persalinan (mixed juice) yang telah dihabiskan oleh ibu setiap 2 jam sekali. Kelompok kontrol ibu dibebaskan untuk mengkonsumsi makanan dan minuman yang dicatat ke dalam formulir record.Analisis data menggunakan Chi-Square, Uji Mann-Whitney, uji $T$ tidak berpasangan, uji kruskal wallis.

Penelitian ini dilakukan setelah mendapatkan izin kelayakan dari komisi etik penelitian kesehatan Fakultas Kedokteran Universitas Padjadjaran.Penelitian ini menerapkan tiga prinsip dasar etik penelitian, yaitu respect to person, beneficience, dan non maleficience serta justice.

\section{HASIL DAN PEMBAHASAN}

1. Hasil Analisis Mutu Mixed juice Minuman mixed juice dibuat dengan menyesuaikan dengan standar pembuatan minuman sesuai SNI pada ibu hamil. 
Tabel 1.Hasil Uji Mutu Minuman Mixed juice

\begin{tabular}{|c|c|c|c|c|}
\hline \multirow[b]{2}{*}{ Karakteristik } & \multirow[b]{2}{*}{ Satuan } & \multicolumn{2}{|c|}{ Mixed juice } & \multirow[b]{2}{*}{ Syarat Mutu } \\
\hline & & $\begin{array}{c}\text { Rasa } \\
\text { Mangga }\end{array}$ & $\begin{array}{c}\text { Rasa } \\
\text { Jambu }\end{array}$ & \\
\hline Air & $\%$ & 77,2 & 76,6 & - \\
\hline $\mathrm{Abu}$ & $\mathrm{G}$ & 0,01 & 0,01 & Maksimal 1,1 \\
\hline Lemak & $\begin{array}{l}\%, \mathrm{~b} / \mathrm{b} \\
/ \mathrm{Kkal}\end{array}$ & $1,7 / 15,9$ & $1,69 / 16,1$ & $\begin{array}{c}\text { Minimal 0,6g/ 5,4 } \\
\text { kkal }\end{array}$ \\
\hline Protein & $\begin{array}{l}\%, \mathrm{~b} / \mathrm{b} \\
/ \mathrm{Kkal}\end{array}$ & $1,79 / 7,2$ & $1,7 / 7,4$ & $\begin{array}{l}3,2-4,4 \text { g/ 12,8-17,6 } \\
\text { kkal }\end{array}$ \\
\hline Karbohidrat & $\begin{array}{l}\%, \mathrm{~b} / \mathrm{b} \\
/ \mathrm{Kkal}\end{array}$ & $20,1 / 83,1$ & $19,9 / 83,5$ & $\begin{array}{c}\text { Maksimal 11,4 g/ 45,6 } \\
\text { kkal }\end{array}$ \\
\hline Kalori/Energi & Kkal & 105 & 107 & Minimal 56 kkal \\
\hline
\end{tabular}

Tabel 1 menggambarkan hasil uji mutu minuman mixed juicesudah sesuai dengan syarat SNI minuman untuk ibu hamil.

2. Hasil Evaluasi Mixed juice

Hasil Evaluasi mixed juicesesuai dengan standar SNI minuman untuk ibu hamil.Evaluasi mixed juice dilakukan dengan memperhatikan dalam hal warna, aroma, rasa, tekstur, dan jumlah persaji yang sesuai dengan kebutuhan ibu bersalin.

Tabel 2. Hasil Evaluasi Mixed juice

\begin{tabular}{|c|c|c|c|}
\hline Karakteristik & Rasa Mangga & Rasa Jambu & $\begin{array}{c}\text { Standar Mutu } \\
\text { Minuman }\end{array}$ \\
\hline Warna & Kuning & Merah muda & Normal \\
\hline Aroma & Dominan mangga & Dominan jambu & Normal \\
\hline Rasa & Dominan mangga & Dominan jambu & Normal \\
\hline $\begin{array}{l}\text { Tekstur } \\
\text { (viskositas) }\end{array}$ & $340,0 \mathrm{mPa} . \mathrm{s}$ & $360,0 \mathrm{mPa} . \mathrm{s}$ & - \\
\hline Jumlah per saji & $300 \mathrm{ml}$ & $300 \mathrm{ml}$ & - \\
\hline
\end{tabular}

Tabel 2 menggambarkan hasil evaluasi mixed juice sudah sesuai dengan standar SNI minuman untuk ibu hamil.

3. Hasil Analisis Uji Cemaran Mikroba dan Escherichia Coli (E. Coli) pada Mixed juice

Uji cemaran mikroba dan Escherichia coli dilakukan pada kedua varian rasa mixed juice. Dimana uji cemaran berguna untuk melihat mikroba yang terkandung didalam produk untuk mengetahui daya simpan suatu produk dan untuk mencegah terjadi gangguan kesehatan yang dapat diakibatkan oleh mikroba dan Escherichia coli. 
Tabel 3. Analisis Uji Cemaran Mikroba dan Escherichia Coli pada Mixed juice

\begin{tabular}{|c|c|c|c|}
\hline Jenis uji & Satuan & $\begin{array}{l}\text { Minuman Mixed } \\
\text { juice }\end{array}$ & Syarat Mutu (Pasteurisasi) \\
\hline \multicolumn{4}{|c|}{ Angka Lempeng Total (suhu chiller) } \\
\hline Hari ke-1 & & $2,61 \times 10^{3}$ & \multirow{4}{*}{ Maks. $1 \times 10^{5}$} \\
\hline Hari ke-2 & Koloni/g & $2,06 \times 10^{3}$ & \\
\hline Hari ke-3 & $(\mathrm{ml})$ & $1,92 \times 10^{4}$ & \\
\hline Hari ke-4 & & $2,87 \times 10^{4}$ & \\
\hline \multicolumn{4}{|c|}{ Pemeriksaan E. Coli (suhu chiller) } \\
\hline Hari ke-1 & & 0,0 & \multirow{4}{*}{ Negatif } \\
\hline Hari ke-2 & & 0,0 & \\
\hline Hari ke-3 & MPN/g & 0,0 & \\
\hline Hari ke-4 & & 0,0 & \\
\hline
\end{tabular}

Tabel 3 menggambarkan hasil analisis cemaran mikroba dan E.coli padamixed juice dimana hasil analisis menunjukkan nilai yang terkandung di dalam mixed juicesesuai dengan standar SNI 01-7148-2005 yang dilakukan pengujian selama 4 hari. Artinya mixed juice aman dikonsumsi sampai 4 hari yang disimpan pada suhu chiller.
4. Karakteristik Subjek Penelitian

Karakteristik subjek penelitian disajikan untuk mengetahui kesetaraan antara kelompok perlakuan dan kelompok kontrol pada awal penelitian. Kedua kelompok penelitian dibandingkan pada ibu dalam hal usia, gravida, indeks massa tubuh, tingkat kecemasan, pendidikan, pekerjaan dan durasi persalinan. Pada bayi baru lahir dalam hal apgar score dan berat badan bayi baru lahir.

Tabel 4. Karakteristik Subjek Penelitian

\begin{tabular}{lccc}
\hline \multirow{2}{*}{ Karakteristik } & \multicolumn{2}{c}{ Kelompok } & Nilai $\mathrm{p}$ \\
\cline { 2 - 3 } & $\begin{array}{c}\text { Intervensi } \\
(\mathrm{n}=30)\end{array}$ & $\begin{array}{c}\text { Kontrol } \\
(\mathrm{n}=30)\end{array}$ & $0,149^{*}$ \\
\hline Karakteristik Ibu & & & \\
a. Usia (th) & 11 & 9 & \\
$20-24$ & 11 & 6 & \\
$25-29$ & 8 & 15 & $0,011^{*}$ \\
$30-35$ & $26,3(4,5)$ & $28,3(5,5)$ & \\
x (SD) & $20-35$ & $20-35$ & \\
Rentang & & & $0,573^{*}$ \\
b. Pendidikan & 9 & 20 & \\
Dasar & 18 & 7 & \\
Menengah & 3 & 3 & \\
Tinggi & & & \\
c. Pekerjaan & & &
\end{tabular}


Bekerja

Tidak Bekerja

d. Gravida

Primigravida

Multigravida

e. Indeks Massa

Tubuh

$\mathrm{x}(\mathrm{SD})$

median

rentang

f. Tingkat

Kecemasan

Tidak ada

kecemasan

Kecemasan ringan

Kecemasan sedang

g. Durasi

Persalinan

$\mathrm{x}(\mathrm{SD})$

median
8

22

14

16

$21,2(1,8)$

21,2

18,5-24,9

23

6

1
10

20

12

18

$21,6(1,8)$

21,6

18,6-24,9
$0,602 *$

$0,407 * *$

$0,453^{*}$

4

0

rentang

Ket: *) Uji Kai kuadrat, **)Uji T tidak berpasangan

Tabel 4 menggambarkan karakteristik ibu tampak usia, gravida, indeks massa tubuh, tingkat kecemasan, pekerjaan dan durasi persalinan antara kelompok yang mixed juice dan yang diberi kebebasan mengkonsumsi makanan dan minuman tidak menunjukkan ada perbedaan yang bermakna $(\mathrm{p}>0,05)$. Untuk tingkat pendidikan menunjukkan ada perbedaan yang bermakna $(\mathrm{p}<0,05)$, pada kelompok intervensi sebagian besar tingkat pendidikan menengah (60\%), sedangkan pada kelompok kontrol sebagian besar tingkat pendidikan dasar (67\%). Karena tingkat pendidikan bermakna maka akan diperhitungkan sebagai variabel perancu.

5. Perbedaan Asupan Energi Ibu Bersalin

Tabel 5.Perbedaan Asupan Energi pada Kedua Kelompok Penelitian setelah dilakukanIntevensi

\begin{tabular}{lccc}
\hline \multirow{2}{*}{ Karakteristik } & \multicolumn{2}{c}{ Kelompok } & \multirow{2}{*}{ Nilai $\mathrm{p}^{*}$} \\
\cline { 2 - 3 } & $\begin{array}{c}\text { Intervensi } \\
(\mathrm{n}=30)\end{array}$ & $\begin{array}{c}\text { Kontrol } \\
(\mathrm{n}=30)\end{array}$ & $<0,001$ \\
\hline Output Energi (kkal) & & & \\
Kategori Energi: & 30 & 1 & \\
Sesuai & 0 & 29 & \\
Tidak sesuai & $123,7(27,5)$ & $45,8(24,3)$ & \\
$\quad$ x (SD) & $101-198$ & $21-140$ & \\
Rentang & 113,5 & 37 & \\
Median & & & \\
\hline
\end{tabular}

Ket : *)Uji Mann-Whitney 
Tabel 5 menggambarkan terdapat perbedaan kalori antara kelompok intervensi dan kelompok kontrol dimana rerata kelompok intervensi lebih tinggi daripada kelompok kontrol dan perbedaan ini sangat bermakna $(p<0,001)$.

Pada fase aktif persalinan terjadi pengosongan lambung sehingga jika diberikan makanan padat maka penyerapan zat-zat nutrisinya bisa berlangsung lebih lama. Seperti yang disebutkan oleh jurnal bahwa waktu pengosongan lambung pada bentuk caran dan padat berbeda, dimana bentuk cairan berkisar 10 sampai 60 menit, sedangkan bentuk padat berlangsung 3 sampai 4 jam. ${ }^{12}$

Proses persalinan terutama kala II terjadi peningkatan kontraksi pada otot rahim yang menyebabkan menurunnya suplai darah dan oksigen yang dibutuhkan oleh otot untuk mengubah glukosa menjadi energi. Metabolisme anaerobik biasanya terjadi pada kegiatan yang memerlukan energi besar dan secara singkat. Energi yang dihasilkan berasal dari proses glikolisis dan simpanan fosfokrantin yang memecah glukosa dari cadangan glikogen yang ada diotot dan hati. Metabolisme anaerobik selain menghasilkan energi, juga menghasilkan produk sampingan berupa asam laktat. Kala II dibutuhkan energi dalam jumlah besar secara singkat, sehingga apabila laktat yang semakin meningkat dan tidak diubah menjadi glukosa maka akan terjadi peningkatan kadar laktat yang dapat mengakibatkan penumpukan asam laktat yang merupakan indikator kelelahan pada ibu bersalin. Agar tidak menggunakan cadangan glikogen yang terlalu berlebihan di dalam tubuh, maka selama persalinan memerlukan asupan nutrisi dari makanan/ minuman dari luar tubuh sebagai sumber glukosa.Dalam jurnal "Does oral carbohydrate supplementation improve labour outcome? A systematic review and individual patient data meta-analysis " oleh Malin et all tahun 2016, disebutkan bahwa kebutuhan energi wanita bersalin telah diestimasikan 50-100 kkal/ jam. ${ }^{1,13}$

\section{SIMPULAN}

Pemberian Mixed juiceselama persalinan memberikan asupan energi yang lebih tinggi, mencegah kenaikan kadar laktat bayi baru lahir dan memberikan kepuasan pada ibu bersalin.

\section{SARAN}

Disarankan kepada peneliti lain agar melakukan penelitian lainnya yang memeriksa unsur fitokimia pada setiap bahan untuk melihat efek yang timbul dari setiap bahan.

\section{DAFTAR PUSTAKA}

1. Li W-h, Zhang H-y, Ling Y, Jin S. Effect of prolonged second stage of labor on maternal and neonatal outcomes. Asian Pacific journal of tropical medicine. 2011;4(5):409-11.

2. Nordström L, Achanna S, Naka K, Arulkumaran S. Fetal and maternal lactate increase during active second stage of labour. BJOG: An International Journal of Obstetrics \& Gynaecology. 2001;108(3):263-8. 
3. Shah S, Tracy M, Smyth J. Postnatal lactate as an early predictor of short-term outcome after intrapartum asphyxia. Journal of perinatology. 2004;24(1):16-20.

4. Datta S, Kodali BS, Segal S. Maternal Physiological Changes During Pregnancy, Labor, and the Postpartum Period. Obstetric Anesthesia Handbook: Springer; 2010. p. 1-14.

5. Bogdanov S, Jurendic T, Sieber R, Gallmann P. Honey for nutrition and health: a review. Journal of the American College of Nutrition. 2008;27(6):677-89.

6. Patel mariam, mary v. Nutritional Analysis (Macronutrients, Potassium and Iron Content) of Four Palm Date Varieties (Phoenix dactylifera L.) and Study of Consumption Pattern among Muslim and Maharashtrian Community. J Food Processing \& Beverages. 2015;3(1):9.

7. Dakappa SS, Adhikari R, Timilsina SS, Sajjekhan S. A review on the medicinal plant Psidium guajava Linn.(Myrtaceae). Journal of Drug Delivery and Therapeutics. 2013;3(2).

8. Sari FM. Pembuatan Manisan Mangga (Mangifera Indica L.) Dengan Memanfatkan Sirup Glukosa Hasil Hidrolisis Selulosa Kulit Buah Kuini (Mangifera
Odorata G.) Menggunakan Hcl 30\%. 2013.

9. Etebu E, Nwauzoma A. A review on sweet orange (Citrus sinensis L Osbeck): health, diseases and management. Am J Res Commun. 2014;2:33e70.

10. Haryono s. bertanam 30 jenis sayuran. 2 ed. jakarta: penebar swadaya; 2004.

11. Astuti SD, Andarwulan N, Hariyadi P, Agustia FC. Formulasi dan Karakterisasi Cake Berbasis Tepung Komposit Organik Kacang Merah, Kedelai, dan Jagung. Jurnal Aplikasi Teknologi Pangan. 2014;3(2).

12. Kong F, Singh R. Disintegration of solid foods in human stomach. Journal of food science. 2008;73(5):R67-R80.

13. ayu pramitasari, basirun al umah, qamar ul. Penerapan asuhan sayang ibu selama proses persalinanDi bidan wilayah puskesmas gombong I dan gombong II. Jurnal Ilmiah Kesehatan Keperawatan. 2010;6(3).

14. Mohan DR, Kumar KS. A study on the satisfaction of patients with reference to hospital services. Int J Bus Econ Manag Res. 2011;1(3):15-25.

15. Tsiotsou R. The role of perceived product quality and overall satisfaction on purchase intentions. International journal of consumer studies. 2006;30(2):207-17. 